\title{
Still Burning
}

\author{
Shawn L Ralston, MD, MS
}

Department of Pediatrics, Johns Hopkins University School of Medicine, Baltimore, MD; Johns Hopkins Children's Center, Baltimore, MD.

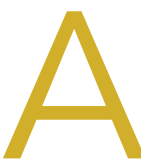

celebratory mood pervaded the last week of service for my ward team at the end of the academic year. As the attending, it was just another day, but it was hard not to be caught up in the general feeling of a milestone flying past. Like most days in a hospital, this one passed in a rhythm of alternating mundanity and crisis. Late in the afternoon, one of the residents called me to a bedside for help. Imagining that my diagnostic skills were urgently required, I took the stairs. The problem, as it turned out, was not strictly medical.

I could hear the yelling before I cleared the locked entry doors to the ward. It doesn't really matter what the yelling was about, just that there is often yelling and there is always very little I can do about the root cause of it. As I stepped into the middle of the conflagration, I remembered the story an intern told me about the night earlier in the month when it fell to her to wheel the same patient's intoxicated parent down to the emergency department. After sleeping it off, the parent was diagnosed with an "allergic reaction" and given a prescription for diphenhydramine. We all knew the diagnosis was fantasy, and yet we all went along with it because there was simply no help available for the root cause of the problem. State social services was already involved, and we had a "safety" plan in place for discharge. As meager as that may have been, we had done the best we could to balance the risk with the available resources... or so we told ourselves.

As a nation, we have chosen not to provide much of a social safety net for our citizens who suffer from addiction and/ or mental illness and, most importantly, for those who've just not had a leg up on the economic ladder. As a hospital-based clinician, I know that people in distress lose their cool and yell sometimes. Ironically, they may yell most loudly at people who sincerely want to help, simply because others do not engage them. Medical schools don't teach us how to handle the yelling, though many would say it is part of the hidden curriculum. One thing that distinguishes many pediatricians like myself is a willingness to listen to the yelling, to engage with it, and to try to help. Not surprisingly, our reputation around the hospital is that we skew a bit naive.

It is worth asking, though: Are pediatricians naive? Sure, we make funny faces. We clown. We baby-talk. Those things

Corresponding Author: Shawn L Ralston, MD, MS; Email: sralsto3@jhmi. edu; Telephone: 443-287-7681.

Published online first April 21, 2021

Received: December 6, 2020; Revised: December 16, 2020; Accepted: December 17, 2020

() 2021 Society of Hospital Medicine DOI 10.12788/jhm.3586 are largely true, but there are other true things about pediatricians. Chief among them is the fact that we come to know some of the worst things there are to know about human beings. Everybody knows people can be awful, but we know exactly how awful they are to defenseless children in precise detail. For instance, I've seen a 4-year-old who was repeatedly starved as a regular punishment. She was so hungry she ate her hair, which turned out to be lucky for her because it caused an intestinal blockage that led to the discovery of the abuse. I gave her an apple one day and she immediately hid it under her shirt. Where you see a scab on a child's inner arm, I see a cigarette burn. I've resuscitated a baby whose parents dipped his pacifier in heroin to stop his crying - the remarkable part of the story being that it was heroin cooked in the hospital bathroom. And then there are the things that I cannot even bring myself to write down.

Carrying this knowledge hollows out a gap between pediatricians and the rest of the world. The divergence between our expectations of how a society should treat its children and the reality of our daily experience grinds away any naivete. The gap becomes a canyon for some of us. We live with the sense that nobody would believe the things we've seen, so we rarely talk about them. Years ago, I was testifying in a (for me) routine child-abuse case where this fact hit home. It is common for juries to disbelieve that a caregiver could do the things we allege. I say allege, but if you work as a pediatrician long enough, the space between allegation and fact narrows. It is simply pattern recognition to you-abuse happens so consistently that we accept it as a diagnostic category. The case in question was a submersion burn, which is an almost unmistakable pattern. The other piece of the story is that it happens to toddlers during toilet training as caregivers lose their selfcontrol and punish children for soiling themselves. For me, simple pattern recognition; for the jury, simply unbelievable. We lost the case.

We are almost always losing the case as pediatricians. Spending on children makes up less than $10 \%$ of the federal budget, whereas spending on the elderly, including Social Security, Medicare, and the adult component of Medicaid, dominates that budget. ${ }^{1}$ Moreover, twice as many children as adults over age 65 are living in poverty in the United States. The Temporary Assistance for Needy Families program is often debated in this country and frequently criticized as wasteful. However, what is not debatable is that the allocated budget (\$16.5 billion) hasn't changed since 1996, resulting in a functional $40 \%$ decrease due to inflation. ${ }^{2}$ Life, for poor children, gets a little tougher every year.

After the resident and I wrapped up our day, we talked a little about how hard it is to witness some of the things you see 
in a children's hospital. I could see the gap between her and the outside world widening right in front of me. In my weaker moments, I want to tell trainees like her to run while they can. I want to warn them that they don't want to know so many of the things we're going to teach them. I know how the story usually ends. I know that our country doesn't promise children safety from social deprivation, hunger, or physical abuse. Instead, we've created the conditions for those things to occur at embarrassingly high rates, and we prosecute the unlucky after the fact. The children are simply collateral damage.

We stood at our patient's bedside and tried to imagine a happy future. Even without his medical problems, he would likely need a major investment of resources in order to thrive. Where would those resources come from? I saw the hospital crib, metal bars on all sides and a thick plastic roof to prevent escape, as a metaphor. Later, I took the elevator down and overheard a snippet of conversation between two residents. One of them asked the other, "How do you know when you've burned out?" The other replied, "I don't know, I guess when you've stopped burning." Burnout is a hot topic in medicine, and some may assume the reasons are obvious: long hours and intellectually demanding work. In reality, those drivers may be less important than the repeated exposure to profound injustice inherent to the practice of medicine in our country.

As hospitalists, we address acute decompensation in our patients and send them back out into the world knowing there will soon be a next time. We also know that the next time might be preventable, if only ... This cycle sometimes feels inexorable, but it can also prompt us to think about our obligation to work toward a more just society. We have to imagine a better future even as we struggle to believe it is on the way.

Most of our hospitals are trying to help. They have communityengagement programs, they purchase housing for homeless patients, they provide large amounts of uncompensated care and sometimes operate at a loss. Yet none of this addresses the root cause of the problem. Medicine, either in the form of an institution or a doctor, can't replace a just society, but the truth of this fact does not mean we should not try.

Pediatrics has always been a field disposed toward advocacy. The origin of our largest professional organization in the United States was the intraprofessional conflict within the American Medical Association (AMA) over the Sheppard-Towner Act of 1921, one of this country's first attempts to address the social determinants of health with legislation. ${ }^{3}$ The American Academy of Pediatrics was formed in 1930 after the AMA House of Delegates rebuked the Pediatric section for advocating for continuance of the act during the late 1920s. ${ }^{3}$ Perhaps what Pediatrics has to teach the rest of medicine is the necessity of making advocacy a part of our professional identity. And perhaps that's the reason that so many pediatricians are still burning and not burned out.

Disclosures: The author has no conflicts to disclose.

\section{References}

1. Committee for a Responsible Federal Budget. Chartbook: budgeting for the next generation. October 11, 2018. Accessed February 2, 2021. http:// www.crfb.org/papers/chartbook-budgeting-next-generation

2. Center on Budget and Policy Priorities. Policy basics: temporary assistance for needy families. Updated March 31, 2021. Accessed February 2, 2021. https://www.cbpp.org/research/family-income-support/temporaryassistance-for-needy-families

3. van Dyck PC. A history of child health equity legislation in the United States. Pediatrics. 2003;112(3 pt 2):727-730 